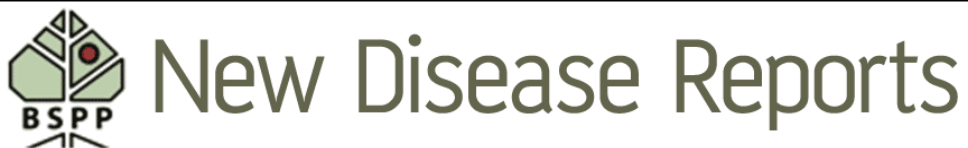

\title{
First report of gladiolus rust caused by Uromyces transversalis in Cuba
}

\author{
E. Martínez-de la Parte ${ }^{1}$, L. Pérez-Vicente ${ }^{1 *}$, T. Cantillo-Pérez $^{1}$, D. Guerrero-Barriel ${ }^{2}$ and A. Ramos ${ }^{3}$ \\ ${ }^{1}$ Central Plant Quarantine Laboratory, Ministry of Agriculture of Cuba, Ayuntamiento 231 between San Pedro and Lombillo, \\ Plaza, Havana City, Cuba; ${ }^{2}$ Santiago de Cuba Provincial Plant Protection Laboratory, Ministry of Agriculture of Cuba; ${ }^{3}$ \\ Enterprise Guira de Melena, Municipal Delegation of Ministry of Agriculture, Güira de Melena, Havana Province, Cuba
}

*E-mail: lperezvicente@live.com

Received: 13 Oct 2010. Published: 19 Apr 2011. Keywords: Uromyces gladioli, Uromyces nyikensis, Gladiolus, foliar disease

In March 2010, rust lesions were observed on leaves of hybrid gladiolus plants in a garden located in the outskirts of Santiago de Cuba city and in a flower production field in Güira de Melena (Santiago de Cuba and Havana provinces respectively).The incidence of the disease in both locations was near $100 \%$ with varying levels of severity. Lesions bearing uredinia were bright orange, variable in shape from globose to oval to transversely elongate. Uredinia (1-3 mm long) were scattered or grouped, orange, elliptical to irregular, and arranged transversely across the leaf (Fig.1). Urediniospores were bright yellow gold, ovate to oblong, and measured 16-26 x 13-19 $\mu \mathrm{m}$ (Fig. 2). The urediniospore wall was hyaline, minutely echinulate and 1.5-2.5 $\mu \mathrm{m}$ thick. Telia were scattered, dark brown, elliptical, bearing nonseptate, light-to-brown teliospores that measured $22-25 \times 14-18 \mu \mathrm{m}$ with an apical thickening measuring 2-4 $\mu \mathrm{m}$. Paraphyses were densely aggregated (Fig. 3).

Three Uromyces species have been reported in gladiolus: Uromyces transversalis, U. gladioli and $U$. nyikensis (Hernández, 2004): $U$. transversalis has been reported in Africa, Europe, Australasia, several South American countries, United States and Mexico. Uromyces gladioli has been reported from several African countries, Argentina and Uruguay, while $U$. nyikensis has been only reported in Zambia and is not considered of economic importance (Hernández, 2004. U. transversalis has transverse sori that develop across the width of the leaves and are up to $3 \mathrm{~mm}$ long, producing telia with paraphyses (teliospores measuring [17.5-] $20-25[-34] \times[14-]$ 15-17.5 [-21] $\mu \mathrm{m}$ ). Uromyces gladioli (teliospores measuring 20-37[-40] $\times 18-26 \mu \mathrm{m}$ ) and $U$. nyikensis (teliospores measuring 19-32 $\times 14-22 \mu \mathrm{m})$ lack transverse sori and produce telia without paraphyses(Smith et al., 1992). On the basis of these characters, the rust was identified as Uromyces transversalis (Hernández, 2004). This is the first report of $U$. transversalis causing gladiolus rust in Cuba.

\section{References}

Hernández JR, 2004. Systematic Mycology and Microbiology Laboratory, ARS, USDA. Invasive Fungi. Gladiolus Rust. Retrieved April 6, 2010, from http://nt.ars-grin.gov/sbmlweb/fungi/index.cfm.

Smith IM, McNamara DG, Scott PR, Harris KM, eds, 1992. Quarantine Pests for Europe. Wallingford, UK: CAB International with EPPO.

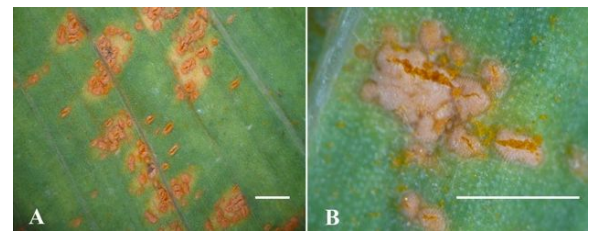

Figure 1

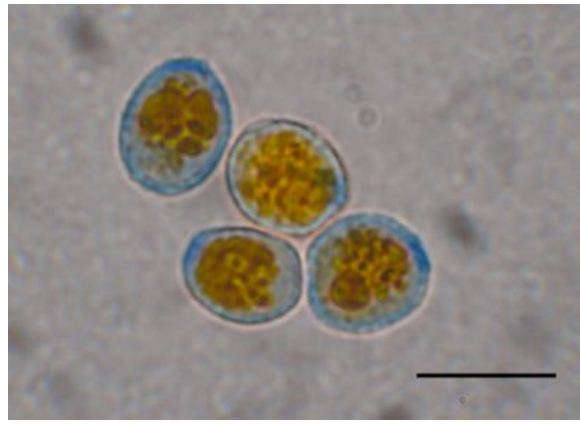

Figure 2

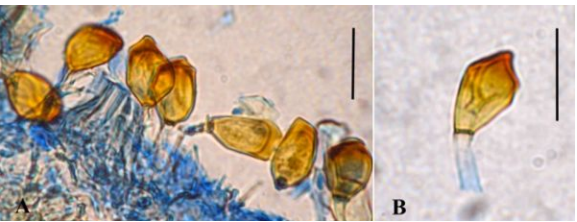

Figure 3

To cite this report: Martínez-de la Parte E, Pérez-Vicente L, Cantillo-Pérez T, Guerrero-Barriel D, Ramos A, 2011. First report of gladiolus rust caused by Uromyces transversalis in Cuba. New Disease Reports 23, 20. [doi:10.5197/j.2044-0588.2011.023.020] 